\title{
Do Pension Plans with Participant Investment Choice Teach Households to Hold More Equity?
}

\author{
Scott Weisbenner \\ Federal Reserve Board \\ May 1998 \\ Revised October 1999
}

\begin{abstract}
Some retirement plans allow the participant to choose how funds are invested. Having to direct investments may provide the participant with financial education. This paper finds that households covered by pension plans in which the employee chooses investments are significantly more apt to hold stock outside of their retirement plan than are households with pension plans offering no such choice. The effect of investment choice upon non-pension asset allocation cannot be explained by portfolio rebalancing or differences in income and saving preferences across households. This provides some evidence that the design of a pension plan can influence an employee's financial decisions.
\end{abstract}

JEL Classification: H31, J33, G11

Key Words: participant-directed plan, portfolio choice

I thank Jeff Brown, Courtney Coile, Peter Diamond, Jonathan Gruber, Jerry Hausman, Martha Starr-McCluer, Jim Poterba, and Martha Scanlon for useful comments. Financial support from the National Science Foundation and the National Institute on Aging through the National Bureau of Economic Research is gratefully acknowledged. The views presented are solely those of the author and do not necessarily represent those of the Federal Reserve Board or its staff. 
The past two decades has seen a dramatic shift in private pension plans. In $1975,39 \%$ of the workforce was covered by a defined benefit pension plan and only $14 \%$ was covered by a defined contribution plan (U. S. Department of Labor (1997)). Eighteen years later, defined contribution plan coverage is nearly $37 \%$ while about one in four workers have a defined benefit plan. ${ }^{1}$ Workers now play a more active role in providing for their retirement through work. Many defined contribution plans, most notably 401(k)s, allow participants to control the level of contributions and in some cases direct how assets are invested. ${ }^{2}$ While much attention has been given to how such retirement plans affect the level of saving (Poterba, Venti, \& Wise (1996), Engen, Gale, \& Scholz (1996)), less research has addressed how they affect a household's composition of saving or portfolio decisions. Given the equity premium observed in the United States this century, the question of how people save is as relevant as the amount they save. ${ }^{3}$ Previous studies of investment allocation within pension accounts generally do not have or do not exploit information on non-pension investments. This paper adds to the literature by testing whether the design of a pension plan can impact a household's non-pension asset allocation.

My hypothesis is that retirement plans in which workers are given a choice as to how assets are invested provide financial education to workers they may not otherwise receive. Household saving/investment decisions are particularly prone to procrastination because the cost of a short-term delay in planning is low and there is a fixed cost in acquiring the information needed to make decisions. ${ }^{4}$ The financial planning employees are "forced" to do when deciding how to invest their pension plan assets eliminates this fixed cost and thus may cause households to adjust the composition of their non-pension (own-account) assets as well. Having to decide between investing in a stock or bond fund, seeing first hand the current and historical return performance of equities versus fixed income securities, and realizing the relative ease with which

\footnotetext{
${ }^{1}$ A defined benefit (DB) plan is a formula-based retirement plan. The typical DB plan provides a lifetime nominal annuity at retirement, with the benefit being a function of years of service, highest salary earned, etc.. In a defined contribution (DC) plan, employees make contributions to an individual account based on employee salary, employee contributions, employer match, and/or employer profits. The worker is responsible for gains and losses that accrue in the account. Examples of DC plans are money purchase plans, ESOPs, thrift or savings plans, TIAA-CREF, and 401(k)s. In 1993, contributions to 401(k) plans accounted for over 2/3 of total DC plan contributions (Bassett, Fleming, \& Rodrigues (1998)).

2 The GAO (1997) reports that 1993 Form 5500 filings indicate that $65 \%$ (73\% when weighted by assets and $73 \%$ when weighted by participants) of $401(\mathrm{k})$ plans with 100 or more participants were participant-directed.

3 The reader should see Campbell, Lo, \& MacKinlay (1997) and Siegel \& Thaler (1997) for a discussion and review of the equity premium literature.

4 Akerlof (1991) and O'Donoghue \& Rabin (1999) present models of procrastination and discuss the consequences for saving.
} 
investments in stocks can be made today (mutual funds, e-trade, etc.) may cause workers to hold equity outside of their retirement plan. Defined contribution plans where the employer makes investment decisions, or formula plans that depend on years of service, wage, age, etc., do not offer this education component.

If one is concerned about the amount of wealth that will be available for retirement, one must be concerned not only about the level of saving, but also about the extent to which financial assets are held in equities. Any program, such as retirement plans with participant choice of investments, which alters perceptions of the "riskiness" or difficulty of investing in stocks, could have important consequences for household consumption during retirement.

Understanding the spillover effects of participant choice is also motivated by the debate concerning Social Security reform. Many Social Security privatization plans (e.g., Gramlich, Scheiber, Forbes) call for universal saving accounts to either replace or complement the existing program, with individuals having a choice between equity and bond funds similar to the Federal Employees' Thrift Plan.

To better understand the effect of participant-choice plans upon non-pension asset allocation, it is useful to examine how the finances of households with various types of pension coverage differ. I exploit variation in the extent to which workers have a choice as to how assets in a retirement plan are invested to test whether an "education" effect is present. Do the portfolios and equity holdings of households who must decide how to invest their pension assets differ from those who do not? If so, are the differences attributable to the education received by being "forced", perhaps for the first time, to make investment decisions (How do I allocate contributions among stock and bond funds?)?

The answer to the first question is yes. Households in defined contribution (DC) plans with participant choice as to how funds are invested are 20 percentage points more likely to hold stock on own-account (i.e., outside of the retirement plan) than are households in DC plans without choice. The answer to the second question is more difficult. Participation in pension plans is not a natural experiment, but rather reflects a conscious decision. One has to be concerned that differences in own-account portfolios simply reflect differences in income level or saving preferences. Plans with choice are not randomly distributed, and at least partly may respond to employees' tastes. Financially savvy and risk-taking individuals may select into jobs with DC plans where workers have a choice as to how assets are invested or financially savvy 
workers may request that employers provide participant-directed pension plans. Thus, caution must be exercised when interpreting the causality behind the correlation between choice and stock ownership.

However, while there are observable differences in income and saving preferences across households with investment choice in their DC plan versus those without, these differences do not appear to be driving the link between investment choice in the pension plan and equity ownership outside of the plan. Among households covered by one DC plan, having investment choice in one's pension plan is estimated to increase non-pension stock ownership by 18 percentage points after controlling for demographics, the financial situation, and saving preferences of the household. This is only three percentage points less than the observed (unconditional) difference in stock ownership across the two groups.

Alternative hypotheses, such as portfolio rebalancing, are considered but are shown to not explain the differences in equity ownership outside of the retirement plan. I also examine a segment of the population which is "financially unsavvy", and for whom there are less differences in observable characteristics across households with and without investment choice in their pension plan, to further test if differences in equity ownership can be identified as an education effect. Overall, the results suggest pension plans with choice may alter household portfolio allocation, leading to a higher probability of owning stock outside of the DC plan. This suggests that the design of the pension plan impacts employee finances. Such a change in asset composition could have a nontrivial impact on a household's future wealth, given the equity premium observed historically in the United States.

The paper will proceed as follows. Section 1 reviews the relevant literature on retirement plans and saving, education and saving, and behavioral economics. Section 2 describes the Survey of Consumer Finances, the primary data set used for this study, and provides demographic and financial attributes of households with different retirement plan coverage. The estimation strategy for determining whether directing pension plan investments causes households to change the composition of their non-pension financial assets will be presented in Section 3. That section also presents results. Robustness checks such as focussing attention on the "financially unsavvy", restricting the sample to 401(k) plans, and testing for substitution between retirement account and own-account stock holdings follow in Section 4. Section 5 offers brief conclusions. 


\section{Literature Review}

This study draws from the literatures on retirement plans and saving, education and saving, and behavioral economics. The contribution of this paper is that it focuses upon how pension plans may influence the composition of saving. The returns historically available to investors indicate that the composition question is just as important as the level question. Other studies of investment allocation within pension accounts typically do not have much/any information on non-pension investments. This paper adds to the literature by testing whether the design of a pension plan can impact a household's non-pension asset allocation.

Research into pension plans and saving dates back at least to the work of Katona (1965) and Cagan (1965) who observed that those with pension plans save more directly than those without. This relationship runs counter to the predictions of a simple life-cycle model in which pension wealth should offset private wealth dollar for dollar. They attribute this finding to "education" or "recognition" effects, thus positing that saving preferences are endogenous. However, this interpretation is clouded because of saving heterogeneity across the population.

Since then, many researchers have further analyzed the relationship between pension and non-pension wealth. Gale (1995) provides a review of this work and concludes that, "taken at face value, the literature shows little offset between pensions and other wealth; most of the studies suggest offsets of 20 percent or less, and almost half suggest either no offset at all or a positive effect of pensions on other wealth." However, Gale (1998) argues such results are plagued by multiple biases and after correcting for many of these finds relatively high levels of

offset. Gustman \& Steinmeier (1998) address many of the concerns raised by Gale and find that pensions cause little, if any, displacement of other forms of wealth for a cohort of 51 to 61 year olds. The one conclusion that can be drawn from this literature is that no strong consensus has emerged regarding the spillover effects of pensions upon non-retirement account finances.

A voluminous literature has studied what effect 401(k) plans in particular have had upon household wealth accumulation (see Engen, Gale, \& Scholz (1996) and Poterba, Venti, \& Wise (1996) for a review). This literature has not focused attention, however, on how 401(k) plans may have affected the composition of household assets. Particularly relevant for this paper, this debate has brought out the concern that employers offer 401(k) plans to satisfy a workforce of 
innate savers, or that employees who are pre-disposed to save seek out firms with pension plans matching their preferences.

Bayer, Bernheim, \& Scholz (1996) (hereafter BBS), Bernheim \& Garrett (1996) (hereafter BG), and Bernheim, Garrett, \& Maki (1997) (hereafter BGM) all study the impact of direct financial education upon the level of saving. BBS \& BG focus on investment education in the workplace using surveys of firms and households, respectively. BBS find retirement seminars increase contributions to savings plans and BG find positive effects of financial education upon both saving in general and saving for retirement in particular. ${ }^{5} \mathrm{BG}$ also find evidence of spillover effects across spouses. BGM study the impact of education on saving decisions by exploiting cross-sectional and time series variation in high school requirements for financial planning courses. They also conclude direct education can influence financial decisionmaking.

The work of Bernheim and others suggests that direct education (e.g., seminars and classes) may have important effects on saving behavior. None of the studies address how the composition of assets is affected by investment education. This paper is also different from previous work in that it studies whether the less direct "education" acquired simply through having to allocate assets in an employer sponsored retirement plan impacts portfolio decisions. This raises the key question: In actuality do workers who participate in a DC plan in which they choose how the funds are invested receive any basic information about the investment options from the employer, and do they have many investment options from which to choose?

Section 404 (c) of ERISA specifies when an employer is not liable for investment results when he provides participant choice. The 404 (c) regulations require that the plan offer a broad range of investment choices (at least three core options must present materially different risk/return characteristics), allow participants to give investment instructions concerning the three core options at least quarterly, and provide sufficient information for informed investment choices. The Employee Benefit Research Institute (1994 \& 1995) reports 73\% of 401(k) participants are provided some educational material. Further, $92 \%$ of 401(k) participants read materials given by employers and $44 \%$ say doing so causes them to invest differently. Typical

\footnotetext{
5 An inherent problem in interpreting their results is that the presence of a saving program could be systematically tied to worker preferences. The direction of the bias is not clear, though. Firms may provide investment education to satisfy the demands of a workforce predisposed to save or firms whose workforce has a segment which is not
} 
investment options are corporate equity (sometimes a firm's own stock), guaranteed investment contracts, U. S. government securities, corporate bonds, and balanced funds. The mean number of investment options provided by employees is 5.4 (Buck Consultants (1994)), so there is some choice to be made.

Benartzi \& Thaler (1998) present evidence that casts some doubt on the financial education 401(k) participation provides. Looking at a database of retirement plans, the authors find that the proportion of assets invested in stocks depends strongly on the proportion of stock funds in the plan. At least in the sample of retirement plan participants they examine, there appears to be a framing effect as investments chosen appear to depend upon the make-up of the funds offered in the plan. This suggests we might expect any spillovers to own-account investing to be minimal. If participants continue to invest equally across all investment options provided, regardless of characteristics, it is doubtful they have acquired any financial education that they can apply to their non-pension finances. However, education need not occur only at the time of the first allocation decision. Participants may split funds among alternatives initially, and then adjust as they observe the pattern of returns across plan alternatives.

Most in spirit with this paper, Papke (1998) also investigates the economic impact of participant-directed retirement plans. However, her question of interest is distinct from mine. She examines how asset allocation, participant contributions, and account balances within the retirement plan differ across account-based plans with and without employee investment choice. Her preferred estimates indicate that participants with choice invest 15 percentage points more in stocks and contribute almost 5 percentage points more in salary. She does not consider spillover effects upon non-pension (own-account) assets. She also utilizes a different data source than this paper. Her sample is drawn from the 1992 National Longitudinal Survey of Mature Women, which is a sample of women aged 55-69 and their husbands. Bajtelsmit \& VanDerhei (1997), Hinz, McCarthy, \& Turner (1997), and Sunden \& Surette (1998) also examine how asset allocation in defined contribution accounts differs across demographic characteristics, such as age and gender, and income levels. However, none of these studies consider how pension plans may influence non-pension asset allocation.

predisposed to save may be more apt to offer seminars in order to relax nondiscrimination rules. BBS and BG present evidence that education is remedial, suggesting their results are biased downward. 
At this point it is natural to ask, why should participation in a retirement plan with participant choice alter a worker's perceptions of risk and provide any financial education. Shouldn't the worker receive this information on his own? Undoubtedly inertia, procrastination, or psychic costs provide what are perceived by some households to be real impediments to investing more heavily or at all in stocks. For example, King \& Leape (1987) report that about $40 \%$ of non-stockholders in the Survey of Consumer Financial Decisions stated that "they did not know enough about the stock market" as a reason for not holding equity.

In a behavioral economics context, participation in a retirement plan with participant choice could have important repercussions (see Thaler (1994) for a discussion of psychology and saving behavior). Time-inconsistent preferences coupled with a misprediction of one's own time-inconsistent preferences (one doesn't predict one will keep putting things off) are likely to lead to procrastination in planning for future events and making decisions, even decisions as important as investing for retirement (Akerlof (1991) and O’Donoghue \& Rabin (1999)). “A clear moral of the procrastination model is that time inconsistent behavior is especially apt to occur when there is some fixed cost (perhaps not very great) to beginning a task ... and the per period cost to delay is low (Akerlof (1991), p. 6)." Household financial decisions generally satisfy these conditions. Requiring workers to make investment choices in their pension plan would likely have little spillover effect on own-account finances in a rational-choice model. However, if households tend to put off thinking about how to best save for retirement, then having employees decide at work how to best invest their 401(k) contributions will eliminate the fixed cost of financial planning. This may cause households to quit procrastinating and adjust the composition of their non-pension assets as well. ${ }^{6}$

Benartzi \& Thaler (1995) propose a model in which investors gain utility not from wealth levels but from returns, and households are loss averse. A household's attitude towards risk then depends crucially upon the time horizon over which returns are calculated. For example, the much greater variability in stock returns over shorter horizons could make stocks look unattractive. The "psychic" damage they inflict upon the investor could outweigh the return premium. A DC plan with participant-directed investments may provide the household with asset return data to utilize when deciding how to allocate contributions across fund options it

\footnotetext{
6 Thaler and Shefrin (1981) discuss the role of Christmas Clubs at work in preventing procrastination and altering saving behavior.
} 
may not obtain otherwise. The employee will likely be presented with historical performance of fund options over time periods from one to five years, and will be provided with account balances on a quarterly basis. Lengthening the time frame over which households evaluate performance, even slightly, will increase their willingness to equitize some of their non-pension financial assets.

\section{Data and Attributes of Households across Pension Plan Coverage}

I use the 1995 Survey of Consumer Finances (SCF). It is a cross-sectional survey taken every three years by the Federal Reserve. The SCF oversamples the rich because asset ownership is skewed, so weights are needed to make the sample data representative of the overall population. The 1995 sample consists of 4,299 households. The SCF has detailed data on asset ownership. It also asks questions concerning pension plan coverage and financial preferences. The 1995 survey has a new question regarding whether the DC plan participant has "any choices about how the money is invested." The main disadvantage of the SCF is that it is a crosssectional data set and not a panel.

My unit of observation is the household because the SCF provides asset data on a household basis and Bernheim \& Garrett (1996) show strong spousal spillover effects. The SCF reports data for up to three pensions per person from his/her current job. I restrict my sample to households where at least one spouse works for pay for an employer and where neither spouse is 65 or older. If the self-employed spouse of a worker sets up a retirement plan for the household, that household is also dropped from the sample. The remaining subsample reflects $54 \%$ of the original sample, or $62 \%$ on a weighted basis.

Households in this subsample fall into one of five categories based on employer-provided retirement plan coverage. ${ }^{7}$

\footnotetext{
7 Note that groups (1) - (4) could be covered by multiple plans. This is because the unit of observation is the household. For example, both spouses may work and be covered. Also, some employers offer multiple pension plans to individual workers. To belong to group (1), the household must be covered by at least one pension plan in which they have control over investments. The household may also be covered by DB plans or DC plans without choice. NOCHOICE households participate in DC plan(s), none of which allow participants to direct investments, and may also have a formula based pension.
} 
(1) household participates in at least one DC plan with investment choice

- referred to as CHOICE (34\% of subsample, $32 \%$ weighted)

- $45 \%$ of these households are covered by just one plan and $31 \%$ have a DB plan as well

(2) household participates in DC plan(s) but none allow investment choice

- referred to as NOCHOICE (12\% of subsample, $12 \%$ weighted)

- $65 \%$ of these households are covered by just one plan and $25 \%$ have a DB plan as well

(3) only have DB plan(s) and not offered DC plan

- $9 \%$ of subsample, $9 \%$ weighted

(4) only have DB plan(s), eligible for but not participating in DC plan

- $6 \%$ of subsample, $7 \%$ weighted

(5) no employer-provided retirement plan

- $40 \%$ of subsample, $40 \%$ weighted

A natural way to study if participant choice in retirement plans has any spillover effect on non-pension finances would be to compare households who participate in a DC plan with choice to households who participate in a DC plan without choice in investments. Thus, I will focus attention on groups (1) and (2) and subsets of these groups. For example, I also examine households covered by just one pension plan (a DC plan with or without participant-directed investments).

Due to the different nature of the pensions, one would expect the financial decisions of DC with choice vs. DB only households to differ regardless of any education effect. For example, a household with a generous DB plan may be more aggressive in own-account portfolio decisions than a household with a $401(\mathrm{k})$ only. The larger is the component of wealth composed of DB benefits, the more a household may wish to increase exposure to risk through own-account investment in stocks. ${ }^{8}$ Including households that have a DB plan and turn down a DC plan in a control group is especially troublesome, as they have revealed a preference not to participate. Finally, households with no pension plan coverage either are not offered a retirement plan or choose not to participate in a firm's plan. Any conclusions drawn by comparing the

\footnotetext{
${ }^{8}$ Since future wages are stochastic and the employee may leave the firm, the actual level of DB benefits is not guaranteed. Also, inflation risk makes the real value of DB pension wealth uncertain.
} 
subpopulation of workers with no pension plan coverage to workers with coverage are dubious given the clear differences between the two groups (both observable and unobservable).

Table 1 shows the financial and demographic characteristics of households with various types of defined contribution plan coverage. Statistics are weighted using 1995 population weights in the SCF. The variables for the most part should be self-explanatory. The demographic variables are defined as follows: "age" represents the maximum age of the head or spouse in the household, "female" indicates whether the household is headed by a single female (by convention males are labeled as the head in couple households), and "college" indicates whether either spouse has attended at least four years of college. The \# of households represents the number of households in the U.S. the specific subsample represents. Income represents before-tax family income in 1994. Net worth represents the sum of financial and non-financial assets less all debt outstanding. It does not include the present discounted value of defined benefit plans, retirement account assets, or Social Security wealth. Financial assets refers to nonpension financial assets. It includes IRA assets but excludes DC plan assets. Stock is defined as direct ownership of stock or stock mutual funds, excluding ownership through retirement accounts (DC plans). As with financial assets, own-account (non-pension) stock includes IRA equity holdings. The ownership of stock on own-account is the key variable of interest.

The construction of a few variables merits some discussion. The SCF asks how DC plan assets are invested. If the respondent answers "mostly or all in stock" or "split between stock or interest earning assets," $100 \%$ or $50 \%$, respectively, of the account balance is assumed to be invested in stock. IRA stock holdings are determined in the same manner as DC plan stock holdings. The reported mean share of financial assets, DC plan assets, or IRA assets invested in stock is the average of each household's share.

I also create four variables to measure saving preferences and attitudes towards risk, both of which may influence the willingness of a household to invest in stock. The SCF records whether or not you have any IRA assets (the stock not the flow). The SCF (Kennickell (1997)) also asks the following question which concerns risk-aversion and thus willingness to invest in equities: 


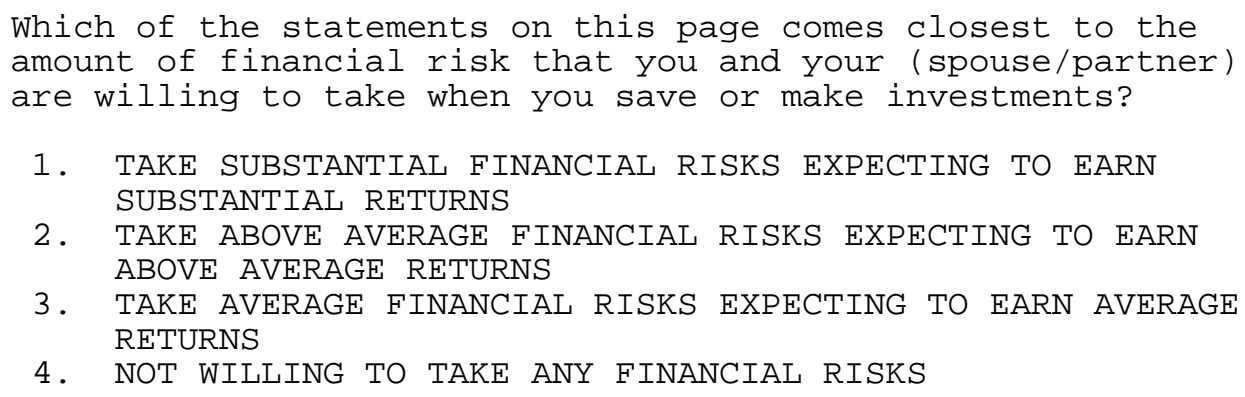

I define the following three dummy variables: HAVEIRA (IRA assets > 0), LOVERISK (answers 1 or 2 to the question), HATERISK (answers 4 to the question). HAVEIRA may indicate a predisposition to save. It is important to note, however, that a past IRA "contribution" could be a rollover of DC plan assets from a previous job rather than a direct contribution. LOVERISK (HATERISK) represents a strong willingness (aversion) to invest in risky assets like stocks.

The variable NOSAVER represents households that do not have IRA assets and are not willing to take above average risks for above average returns. Thus,

NOSAVER = 1 - maximum(HAVEIRA, LOVERISK).

Table 1 demonstrates that households which participate in at least one pension plan in which they determine the investments are much more apt to hold stock outside of their pension plan relative to households covered by a DC plan(s) which does not allow employees choice in investment decisions. Nearly $40 \%$ of households which direct investments in their pension plan(s) hold at least $\$ 1000$ of stock on own-account (equities comprise 1/5 of financial assets on average for this group), while only one in six households with DC plan coverage without employee investment choice hold stock outside of their retirement plan (equities comprise 1/10 of financial assets on average for this group). The differences in equity holdings are similar when we focus on households that are only covered by one defined contribution plan.

Households that have choice in how assets are allocated in pension plans hold more equities on own-account, which is consistent with the education hypothesis, but they also differ in important ways from no choice DC plan households. While the two groups are very similar along demographic variables, households that participate in a DC plan with choice have higher 
wealth and income than families whose DC plan(s) does not allow investment choice. ${ }^{9} 10$ The differences in mean income and net worth are $\$ 19.8 \mathrm{~K}$ and $\$ 58.5 \mathrm{~K}$, respectively, and are still evident when the sample is restricted to households with only one defined contribution plan. Most stark are differences in IRA assets and saving preferences. For example, CHOICE households are 13 percentage points more likely than NOCHOICE households to report being willing to take above average risks to earn above average returns. They are also 12 percentage points more likely to have an IRA. It is important to note, though, that preferences may change over time and that these differences could reflect the "education" received by directing the investment of pension plan assets. Regression analysis is necessary to disentangle how much of the difference in own-account stock ownership across CHOICE and NOCHOICE households is attributable to the presence of investment choice as opposed to differences in income and/or saving preferences.

\section{Estimation Strategy and Results}

Recall, the education hypothesis suggests having employees decide at work how best to invest their retirement funds will educate the employees about financial planning. This education may cause households to start to pay closer attention to their non-pension asset allocation and to start to invest some of their own-account assets in the stock market. Thus, the question of interest is whether requiring employees to decide how to invest retirement account assets also impacts households' non-pension asset allocation. The basic regression model I have in mind is:

$($ own stock $)$ or $($ stock share $)=\beta_{0}+\beta_{1} *$ CHOICE $+\beta_{2} *($ SAVING/RISK preferences $)+$

$$
\beta_{3} * \text { Finances }+\beta_{4} * \text { Demographics }+\varepsilon
$$

\footnotetext{
${ }^{9}$ Some differences in income and net worth across CHOICE vs. NOCHOICE households is by construction, as CHOICE households will by definition be more apt to be covered by multiple plans (1.8 vs. 1.4 plans for NOCHOICE), and will more likely be a two-earner family. Recall, a CHOICE household may also be covered by additional DB plans and DC plans without participant choice, whereas a NOCHOICE household may have supplemental DB plans but no DC plan which allows the participant to control investments. This is why the paper also presents results with the sample restricted to households covered by only one pension plan.

${ }^{10}$ College degree attainment is the only demographic variable that is significantly different across CHOICE and NOCHOICE households in the full sample (CHOICE households are 8 percentage points more likely to have a
} 
Own stock is a dummy that is one if non-retirement account stock and stock mutual fund holdings exceed $\$ 1000$ and stock share is the share of non-retirement financial assets held in stocks or stock mutual funds. CHOICE indicates whether the household participates in at least one pension plan where investments are participant-directed.

The basic "experiment" I am considering is whether, among households with a DC pension, those who direct investment of plan assets are more apt to own stock on own-account. In the broadest test, $\mathrm{CHOICE}$ households are those that are covered by at least one pension plan where they determine how funds are invested. They may have additional DC plans with or without choice and supplemental DB plan coverage as well. The "control" group, for whom CHOICE is zero, will be households participating in at least one DC plan and perhaps covered by a defined benefit plan. However, none of these DC plans allow the participant to direct the investment of assets. Thus, both CHOICE and NOCHOICE households have some provision for retirement through work, but only CHOICE households have input into how the retirement account is managed. As a more refined "experiment", I will also test if there is any education or spillover effect on non-pension investing by focussing on households with only one pension plan which is either a DC plan with investment choice or a DC plan without investment choice.

Categorical variables for various net worth and income levels are included in the specification to reflect that wealthier households can absorb more risk (decreasing relative risk aversion). Preferences may also vary with income/wealth. The same reasoning justifies the inclusion of a "have DB plan" dummy to reflect that having a defined benefit package in addition to the DC plan may alter risk-taking. Age should also be a key explanator. A popular rule of thumb is that the percentage of one's portfolio invested in equities should be 100 minus one's age (Bodie, Merton, \& Samuelson (1992) provide theoretical support for a decline in equity exposure with age). Stock ownership may also decline with age because of cohort effects such as proximity to the Great Depression. College education, marital status, and the sex of the head of the household may also influence saving preferences and risk tolerance.

The key difficulty is how do we measure saving/risk tolerance preferences properly? By omitting controls for them, we potentially introduce an omitted variable bias into the results. 
Perhaps the correlation between CHOICE and non-pension equity ownership reflects an underlying correlation between omitted saving/risk taking preferences and equity ownership, which manifests itself in the CHOICE coefficient. This endogeneity could result from workers either demanding that employers provide, or selecting jobs that offer, retirement plans matching their saving preferences.

Papke (1998) finds that participant choice and plan knowledge are not strongly or significantly correlated among NLS Mature Women respondents. She offers this as evidence that choice is not endogenous. However, the differences in saving preferences and risk tolerance across pension types warrant attention.

There are two econometric strategies one can pursue.

(1) Find proxies that account for saving preferences/risk tolerance.

(2) Attempt to create a "natural experiment" by defining a control group that is otherwise similar to the experimental group, except for exposure to choice in pension plans.

\subsection{Regressions of Stock Ownership/Holdings}

I first adopt strategy (1). HAVEIRA, LOVERISK, \& HATERISK serve as proxies for saving preferences and risk tolerance. It is important to note that preferences need not be fixed. For example, participant choice may provide education that causes households to own more stock outside of their pension, and changes saving preferences and risk tolerance. I thus report results both with and without the saving preferences/risk tolerance proxies.

Table 2 displays the estimation results for the stock ownership and share of financial assets regressions. Because Probit coefficients are difficult to interpret, the coefficients are transformed to reflect marginal changes in probability for a household with average characteristics. The reported results are not weighted (weighting observations with the population weights changes the coefficients very little).

From looking at simple tabs, heterogeneity in households across pension types was evident. The key question is how much of the observed difference in non-pension equity holdings across households with and without investment choice in their DC plan is simply a reflection of differences in demographics, financial situation, and saving preferences and how much is really attributable to investment choice in the pension plan. 
Table 2 provides some evidence on this issue. The marginal effect of CHOICE is estimated to be a 17 percentage point increase in non-pension equity ownership (18\% when focus on households covered by only one DC plan) after controlling for financial, demographic, saving, and risk tolerance covariates. Given that only one in three households hold over $\$ 1000$ of stock outside of their retirement plan, investment choice in the DC plan appears to have a substantial impact upon a household's non-pension asset allocation.

Estimates for the financial and demographic characteristics are generally as expected in the ownership regressions of Table 2. Age, financial status, and college education are consistently important determinants of equity ownership. The estimates imply that, relative to the 30-39 cohort, 60-64 households are nearly 19 percentage points less likely to hold stock outside of their pension. This could reflect an age effect and/or a cohort effect (see Poterba \& Samwick (1997) for evidence on this issue). We see monotonic increases in equity ownership as income and net worth increase. ${ }^{11}$ For example, a household with income exceeding $\$ 150 \mathrm{~K}$ is 11 percentage points more likely to own equity relative to a household in the $\$ 50-75 \mathrm{~K}$ bracket and a household with wealth exceeding $\$ 500 \mathrm{~K}$ is 30 percentage points more likely to own equity relative to a household with wealth of $\$ 50-100 \mathrm{~K}$. A college-educated household is significantly more likely to own stock outside of the retirement account. This is consistent with Haliassos \& Bertaut (1995) who find stock ownership is larger among more educated groups at all income levels. Having defined benefit plan coverage as well increases equity ownership, but the effect is small and insignificant.

The saving preference proxy, IRA ownership, is a very strong and significant predictor of owning stock outside of one's pension plan. However, the inclusion of HAVEIRA, LOVERISK, \& HATERISK in the regression does not substantially alter the estimated impact of participant choice upon equity ownership. To the extent that these variables do a good job of capturing these preferences, this provides some evidence that the coefficient on CHOICE is not being driven by omitted attitudes toward saving/risk tolerance. Similar conclusions are drawn when I focus on households with one pension plan.

\footnotetext{
11 The net worth and income variables are to some extent endogenous. Equity ownership may lead to higher income through dividends and capital gain realizations. I thus included labor income as opposed to total income in the regressions and obtained virtually identical results. The coefficients on the net worth dummies are difficult to interpret as they reflect both that wealthy households are more apt to hold stock and that, given the historical equity premium, households that invested in stock are wealthier. However, the coefficient of interest, namely the impact of CHOICE, is not materially affected by the inclusion or exclusion of the net worth controls.
} 
Papke (1998), Sunden \& Surette (1998), Bajtelsmit \& VanDerhei (1997), and Hinz, McCarthy, \& Turner (1997) all examine whether there are gender differences in investment decisions within the pension plan. The latter three studies find that women tend to invest their retirement plan contributions in less risky assets than do men. In some couples, the husband has a retirement plan with investment choice, while in others the wife does. Are there differential impacts on a household's asset allocation depending upon which spouse has the DC plan with CHOICE? Focussing on married couples covered by one pension plan, the marginal effect on the probability of non-pension stock ownership is .215 (.075) when the husband has the DC plan with CHOICE, controlling for all other household characteristics. This is very similar to the effect when the wife has the DC plan with choice (marginal effect is .227 (.091)). Thus, there is no evidence of differential spousal effects upon household asset allocation in this context.

It is worth noting that the marginal effect of CHOICE, estimated after controlling for all the household characteristics, is still three quarters of the observed (unconditional) difference in the probability of owning stock on own-account between the CHOICE and NOCHOICE households. Focussing on households covered by only one DC plan, the estimated marginal impact of CHOICE only falls from 21 to 18 percentage points with the inclusion of household covariates. Thus, demographics, the financial situation, and proxies for risk tolerance are significant and important predictors of whether a household owns stock outside of the pension. While controlling for them does lessen the effect of investment choice upon non-pension asset allocation, it does so only modestly.

\subsection{Regressions of Share of Assets in Equities}

Table 2 also presents regression estimates for the share of non-pension financial assets held in equities. I present marginal effects derived from a Tobit specification. The pattern of coefficients is similar to that found in the ownership regressions. Evaluated at the sample means, households who direct investments in their DC plan hold 6 percentage points more of their nonpension financial assets in equities. This is a significant and economically substantial effect, given that the average proportion of non-retirement plan financial assets held in equities is .17 for the sample (.14 for the sample of households covered by only one plan). ${ }^{12}$

\footnotetext{
${ }^{12}$ Specifications were also estimated with the equity share of total non-retirement account assets, both financial and nonfinancial, as the dependent variable. Evaluated at the sample means, households who direct investments in their DC plan hold 1.5 percentage points $(\mathrm{t}$-statistic $=5.3)$ more of their total assets in equities relative to those who do
} 
The education hypothesis I have outlined above has predictions regarding the ownership decision, but offers no prediction regarding the amount of stock held conditional on ownership. The education hypothesis suggests having employees decide at work how best to invest their pension assets will educate the employees about financial planning. This education may spillover and cause households to start to pay closer attention to their non-pension asset allocation and to start to invest some of their own-account assets in the stock market. It is more doubtful that, conditional on already owning stock, having a say in how pension assets are allocated will provide much additional education. ${ }^{13}$ Indeed, I find that the positive correlation reported above is driven by the ownership decision. Conditional on ownership, participation in a CHOICE plan has no significant effect on the level of non-retirement account equity holdings (results not reported). ${ }^{14}$ For the remainder of the paper I will focus on stock ownership, as that is where we would predict any educational spillovers to occur.

\section{Robustness Checks}

While suggestive of an education effect, legitimate concerns can be raised with the results and their interpretation. Robustness checks such as focussing attention on the "financially unsavvy", restricting the sample to 401(k) plans, and testing for substitution between retirement account and own-account stock holdings follow below.

\subsection{Results Focussing on "Financially Unsavvy"}

Clearly, caution must be exercised when interpreting the causality behind the correlation between choice and stock ownership. In Section 3, I find that controlling for observable household attributes and preferences does not substantially weaken the observed correlation between non-pension stock ownership and investment choice. This provides some evidence that the impact of CHOICE reflects an education effect, rather than some omitted variable bias.

not. The average for the sample is $4.8 \%$. Similar results are obtained for the restricted sample of households covered by one pension plan.

13 The type of DC plan may impact stock holdings, conditional on ownership, if DC plans without choice invest funds in a systematically undesirable way that is offset by households adjusting non-pension portfolios. I address this possibility in Section 4.

${ }_{14}$ This should not be too surprising given that the ratio of equity holdings to financial assets, conditional on owning stock, is very similar across the two groups. 
Nonetheless, some may be troubled that half of the households which participated in a DC plan with investment choice had IRA assets and/or reported they were willing to take above average risks to earn above average returns, compared to only $1 / 3$ of households with no investment choice. ${ }^{15}$ The open question is do the observable variables, particularly HAVEIRA, soak up all of the "financial savvy" which could explain a correlation between CHOICE and stock ownership? In other words, does the estimated CHOICE coefficient in the full specification represent a pure education effect, or is it still contaminated by unobservable saving preferences that are not accounted for by the observable household characteristics?

To address this concern, I estimate regressions only on the subgroup of households for whom NOSAVER is one. A priori, we would expect these households to be "financially unsavvy". Thus, I drop all observations of households that report having ever invested in an IRA (HAVEIRA=1) or report they are willing to take above average risks to obtain above average returns (LOVERISK=1). The households that I exclude, for whom NOSAVER is zero, may have a predisposition to save and a willingness to invest in equities, even without exposure to participant-directed retirement plans.

This strategy may seem dubious at best, as I am selecting on preferences that are potentially endogenous. For example, participant choice may provide education that causes households to own more stock outside of their pension, and changes saving preferences and risk tolerance (NOSAVER changes from one to zero). Wouldn't selecting a sample based upon a potentially endogenous variable bias the results obtained from the selected sample? The answer is probably yes. However, the bias works against detecting any education effect, as it will tend to bias the estimates downward.

Consider the following thought experiment. Suppose that the household has no pension plan coverage in 1989, but is covered by a DC plan with participant choice in 1992. The researcher only observes the household in 1995. There are four possible household types.

\begin{tabular}{c|c|c|c} 
& 1989 & 1995 & Comment \\
\hline$(1)$ & SAVER & SAVER & Group of households predisposed to save \\
$(2)$ & NOSAVER & SAVER & Group of households for whom "education" effect is largest \\
$(3)$ & NOSAVER & NOSAVER & Education effect is smaller for this group than for group (2) \\
$(4)$ & SAVER & NOSAVER & Unlikely \\
\hline
\end{tabular}

15 This difference could reflect the "education" received by directing the investment of pension plan assets. 
What the researcher would like to know is what effect does having to direct investments in one's pension plan have upon the non-pension finances of households which were "financially unsavvy" back in 1989 (groups (2) and (3)). However, households are only observed in 1995. What I am essentially doing by selecting on the NOSAVER variable is throwing out both those predisposed to save and those for whom the "education" effect of the retirement plan is the largest. Recall from Table 1 that the population that has investment choice in their DC plan has a higher proportion of SAVER households. The researcher does not know if a SAVER observed in 1995 is from group (1) or group (2). Suppose all SAVERS were in actuality from group (1). In this case, attributing the observed correlation between having investment choice in the DC plan and holding stock outside of the DC plan to an "education" effect would be spurious.

By focussing on NOSAVERS observed in 1995, I am left with households for whom the potential education effect of participant-choice plans is smaller. Thus, the results I obtain for this group should be downwardly biased. A zero coefficient on the choice variable does not imply there is no educational component from DC plans with CHOICE, as we are excluding the group of households for whom the education effect is the largest from the sample (group 2). However, narrowing the sample to this select group has the advantage of removing households that may have a predisposition to save.

Table 3 reports characteristics of households across the different types of pension plans (CHOICE and NOCHOICE households in general and then among households with just one plan). The sample is again weighted using 1995 population weights in the SCF. Notice how the CHOICE and NOCHOICE groups are much more comparable in virtually every category except equity ownership on own-account. Among households covered by one plan, the average values of income, net worth, DC plan assets, and all demographic characteristics of households in a participant-directed plan are statistically indistinguishable from those in a plan without choice. Particularly striking is that the level of stock holdings in retirement accounts are very similar across DC plans with and without investment choice.

Table 4 reports regression results, analogous to Table 2 but estimated on the "financially unsavvy" (NOSAVER) households. The point estimates suggest a significant education spillover effect from participant choice (7-8 percentage point change in the probability of nonpension equity ownership) for this subpopulation. This is a rather large effect, given that only one in seven NOSAVER households hold stock outside of their retirement account. The 
financial and demographic explanators are statistically important to the model (p-value of .00 for exclusion test), but their impact on equity holdings does not substantially mitigate the estimated effect of investment choice. This is not a shock, given the similarities across the groups shown in Table 3.

The results in Table 4 provide additional evidence that, ceteris paribus, having investment choice in pension plans alters financial decisions regarding assets held outside of the retirement plan. However, given the selection rule used to obtain the sample, the magnitude of the results obtained should not be extrapolated beyond this subpopulation. The estimated effects are useful for gauging whether an education/spillover effect is really present, but not for measuring the magnitude of that effect for the whole population. For the remainder of the paper, I will report results estimated over the full sample and over the "financially unsavvy" subsample.

\subsection{Other Relevant Differences Across Choice and No-Choice Plans?}

A key argument that can be raised against the results is that DC plans can differ along other margins besides whether investment choice is allowed. For example, there may be a difference in the decision to participate across DC plans with and without choice. Suppose firms that offer plans without investment choice require mandatory participation (e.g., a certain $\%$ of salary is invested in company stock). Suppose firms that offer DC plans with participantdirected investments allow the employee to choose whether he participates. This could obviously present a problem, as the CHOICE coefficient could simply reflect the unobservables of who selects into the plan more so than the presence of investment choice.

Differences do emerge once we categorize DC plans by whether they allow participant choice. For example, 401(k) / 403(b) plans are more apt to allow investment choice than are other DC plans (e.g., profit sharing and employee stock ownership). Among households surveyed in the $1995 \mathrm{SCF}, 401(\mathrm{k}) / 403(\mathrm{~b})$ plans comprise 68\% of all DC plans which allow participant choice, but only $40 \%$ of DC plans which do not allow participants to choose investments. ${ }^{16}$ To the extent that these DC plans differ systematically along other margins besides whether investment choice is allowed, this could potentially present a problem.

\footnotetext{
16 A 401(k) is a salary reduction plan (an agreed upon reduction in employee's salary is used to finance the retirement account). It effectively started in 1982 after IRS clarification of its tax treatment. 403(b) plans are taxsheltered annuities that are funded by employee contributions like 401(k) plans. However, 403(b)s are offered only by schools and non-profit organizations.
} 
Perhaps differences in DC plan characteristics vary across industry or occupation groups in a way that biases the CHOICE coefficient. However, including industry and occupation dummies in the regressions (results not reported) reduces the marginal impact of CHOICE by less than two percentage points for the whole population and less than one point when focusing on the "financially unsavvy". Nonetheless, comparing a worker who voluntarily participates in a retirement plan with one who may be forced to is less convincing than comparing two workers who voluntarily decided to contribute to a retirement plan, one of which happened to allow participants to make investment decisions while the other did not.

To address this concern, I restrict attention from the universe of DC plans to focus just on 401(k) plans. The majority of 401(k) plans offer employees multiple investment options in order to avoid liability and attract contributions. However, as mentioned in the introduction, $27 \%$ of 401(k) plans weighted by participants do not allow employees to direct investments. For the four samples I consider, the percent of 401(k) plans without investment choice ranges from 22-28\%. "The essential feature of a 401(k) plan is the right of an eligible employee to elect to have the employer make contributions to the plan (elective contributions) or to receive them in cash" (The 401(k) Plan Handbook, p. 336). Thus, by focussing on 401(k) plans, worker discretion in deciding whether or not to participate should not vary across plans that do or do not allow participants to direct investments. It is worth mentioning that non-elective contributions may occur to satisfy non-discrimination rules. ${ }^{17}$ I would not expect this activity to vary systematically across plans with or without investment choice.

Table 5 presents stock ownership regression results when I require that a DC plan be a 401(k) / 403(b). Results are generally similar to those obtained by looking at all types of account-based plans, however precision is sacrificed on many demographic and financial covariates due to the reduction in sample size. The probability of non-pension equity ownership is estimated to be 23-27 percentage points (12-14 when focus on "financially unsavvy") higher for 401(k) participants who direct investments relative to 401(k) participants who do not.

\subsection{Portfolio Rebalancing}

To this point I have ignored that households may want to balance their holdings of different assets across retirement and non-retirement accounts. Households may have target

\footnotetext{
17 The firm may make contributions for non-contributing low-income workers to ease the contribution limit faced
} by high-income workers. 
levels of fixed income assets and equity they wish to achieve, and they are willing to adjust retirement account assets and/or non-pension balances to achieve the desired targets. For example, suppose all households have the same desired holding of stock. Also suppose pension plans in which the worker has no choice as to how funds are invested put all the money in company stock. We would then expect the own-account holdings of households with pension plans with participant choice to be composed more of equities relative to those covered by pension plans controlled by the employer. The correlation between CHOICE and own-account stock holdings need not reflect any education spillover, but could simply occur due to such portfolio rebalancing.

It is unlikely that this could be driving the CHOICE coefficient, as the fraction of pension plan assets held in equities is actually fairly similar whether or not the worker gets to direct the investments (see Tables 1 and 3). Roughly 30\% of both CHOICE and NOCHOICE households report most or all of their retirement plan is invested in stock. Nonetheless, I included as extra covariates the fraction of retirement account assets held in the form of stock and dummies for the size of a household's DC plan balance relative to its non-pension financial assets. Besides picking up a substitution effect, the coefficient on the fraction of DC plan assets held in stock could also reflect household preferences and risk tolerance. The categorical variables for the ratio of retirement to non-retirement financial assets are included because the larger is this ratio, the less important it is for a household to worry about how it handles its non-pension portfolio and perhaps the less likely it is to own stock outside its pension plan.

The marginal effect of CHOICE is essentially unchanged after adding the new regressors (results are reported in Table 6). Bodie \& Crane (1997) document a positive correlation in asset composition across accounts when examining TIAA-CREF participants. I also find little evidence for portfolio rebalancing as the equitization of retirement account assets is positively and significantly correlated with non-retirement stock ownership. The strong correlation disappears, however, when we focus on the NOSAVER or financially unsavvy households. This suggests that the extent of equitization in retirement plans helps proxy for preferences and risk tolerance that carry over to own-account portfolios. The results also indicate that households for 
whom the DC plan is a large component (>80\%) of total financial wealth are less apt to own stock outside of their pension. ${ }^{18}$

\subsection{Other Concerns}

My final concerns cannot be addressed by re-examining the data. Recognizing the potential endogeneity of choice, this paper attempts to control for household characteristics that may influence portfolio choice. However, I am not able to control for specific characteristics of the employer beyond broad industry groups. It is important to point out that the presence of choice in the pension plan could be correlated with having a "good" employer. Perhaps these "better" employers are also more apt to offer stable earnings growth, health insurance, and other benefits, which themselves may affect portfolio choice.

There are also concerns about the generalizability of the results obtained. First, is the apparent "education" unique to this period? Do/will we see similar spillover effects in other periods? "Learning" is likely enhanced when annual stock returns are $20 \%+$ per annum. Second, how well can the results be extrapolated beyond the segment of the population upon which I focus. It should be noted that roughly half of the workforce does not participate in a retirement plan (Bassett, Fleming, \& Rodrigues (1998)). Thus, caution must be exerted when trying to extrapolate any results obtained from the workforce covered by a retirement plan to the whole population. An important question, which is beyond the scope of this paper, is how should we expect the segment of the workforce currently not covered by any retirement plan to respond if a partial privatization of Social Security occurs and universal 401(k)-type accounts are introduced?

\section{Conclusion}

This paper studies whether the design of pension plans, in this case who directs the investment of contributions, has an impact on the employee's finances. Specifically, are households that make decisions regarding pension plan investments more apt to hold equity on own-account relative to households whose pension plan assets are controlled by the employer?

\footnotetext{
${ }^{18}$ Of course, this could just be a mechanical result as near zero non-pension assets will imply a large DC plan / financial assets ratio and zero own-account stock ownership. To combat this built in correlation I re-estimated the regression for households with non-retirement financial assets in excess of $\$ 20 \mathrm{~K}$ and found the same pattern in the coefficients.
} 
Using the 1995 Survey of Consumer Finances, I find that households covered by pension plans in which they have investment choice are significantly more apt to hold stock outside of their retirement plan than are households with pension plans offering no such choice. One interpretation of this finding is that having to direct investments may provide the participant with education that influences financial decisions. However, one can argue that the direction of the causality is reversed. The presence of a plan with choice may reflect the preferences of the employee (financially savvy workers select into jobs offering plans with choice). By including covariates for demographics, the financial situation, and proxies for risk tolerance, I attempt to control for preferences that may cause a household to hold stock. Other robustness checks, such as focussing attention on a sample of "financially unsavvy" households and testing for substitution between retirement account and own-account stock holdings, were also conducted to test whether hypotheses other than the education effect could explain the observed correlation between investment choice in pension plans and stock ownership outside of the pension plan.

If this education/spillover effect is real, what is driving it? Are workers able to selfeducate simply by observing the repercussions of their investment choices (learning by doing)? Or do participant-directed plans also provide more or better retirement education through seminars and reading materials that facilitate changes in financial behavior both inside and outside the retirement plan? Somewhat surprisingly, seminars, newsletters, and summary plan descriptions are nearly as common among firms with defined benefit plans as firms offering 401(k)s in the sample of firms Bayer, Bernheim, \& Scholz (1996) examine. Better understanding of what really educates plan participants and drives changes in financial behavior is needed.

This paper has focussed attention on one specific component of pension plans, namely the control of pension plan investments. Another relatively new development in retirement plans is the ability to borrow against the account balance. The 1995 SCF suggests that $55 \%$ of account-based pension plans allow such loans. Future work will study to what extent participants borrow against account balances and whether such an allowance eases liquidity constraints or simply leads to imprudent borrowing against provisions for retirement. 


\section{References}

Akerlof, George A. "Procrastination and Obedience." American Economic Review 81(2) (1991), 1-19.

Bajtelsmit, Vickie L. and Jack L. VanDerhei. "Risk Aversion and Pension Investment Choices," in Michael S. Gordon, Olivia S. Mitchell, and Marc M. Twinney, eds., Positioning Pensions for the Twenty-First Century. Philadelphia: University of Pennsylvania Press, 1997, 45-66.

Bassett, William F., Michael J. Fleming, and Anthony P. Rodrigues. "How Workers Use 401(k) Plans: The Participation, Contribution, and Withdrawal Decisions." National Tax Journal 51(2) (June 1998) 263-289.

Bayer, Patrick J., Douglas B. Bernheim, and John Karl Scholz. "The Effects of Financial Education in the Workplace: Evidence form a Survey of Employers." NBER working Paper No. 5655. Cambridge, MA: National Bureau of Economic Research, 1996.

Benartzi, Shlomo and Richard H. Thaler. "Naïve Diversification Strategies in Defined Contribution Saving Plans." Mimeo, 1998.

Benartzi, Shlomo and Richard H. Thaler. "Myopic Loss Aversion and the Equity Premium Puzzle.” Quarterly Journal of Economics 110 (February 1995), 75-92.

Bernheim, Douglas B., Daniel M. Garrett, and Dean M. Maki. "Education and Saving: The Long-Term Effects of High School Financial Curriculum Mandates." NBER working Paper No. 6085. Cambridge, MA: National Bureau of Economic Research, 1997.

Bernheim, Douglas B. and Daniel M. Garrett. "The Determinants and Consequences of Financial Education in the Workplace: Evidence form a Survey of Households." NBER working Paper No. 5667. Cambridge, MA: National Bureau of Economic Research, 1996.

Bodie, Zvi and Dwight B. Crane. "Personal Investing: Advice, Theory, and Evidence." Financial Analysts Journal (Nov./Dec. 1997), 13-23.

Bodie, Zvi, Robert C. Merton, and William Samuelson. "Labor Supply Flexibility and Portfolio Choice in a Life-Cycle Model." Journal of Economic Dynamics and Control 16 (July/October 1992), 427-449.

Buck Consultants. 401(k) Plans: Employer Practices and Policies. New York, 1994.

Cagan, Phillip. “The Effect of Pension Plans on Aggregate Saving." New York: National Bureau of Economic Research, 1965.

Campbell, John Y., Andrew W. Lo, and A. Craig MacKinlay. The Econometrics of Financial Markets. Princeton, New Jersey: Princeton University Press, 1997. 
Employee Benefit Research Institute. "Retirement Confidence in America: Getting Ready for Tomorrow.” EBRI Special Report SR-27, Issue Brief 156, December 1994.

Employee Benefit Research Institute. "Can We Save Enough to Retire? Participant Education in Defined Contribution Plans.” Issue Brief 160, April 1995.

Engen, Eric M., William G. Gale, and John Karl Scholz. "The Illusory Effects of Saving Incentives on Saving." Journal of Economic Perspectives 10 (Fall 1996), 113-138.

Gale, William G. The Effects of Pensions on Wealth: A Re-evaluation of Theory and Evidence." Journal of Political Economy 106(4) (August 1998), 706-723.

Gale, William G. The Effects of Pensions on Wealth: A Re-evaluation of Theory and Evidence." Mimeo, 1995.

Gustman, Alan L. and Thomas L. Steinmeier. "Effects of Pensions on Savings: Analysis with Data from the Health and Retirement Study." Mimeo, 1998.

Haliassos, Michael and Carol C. Bertaut. "Why Do So Few Hold Stocks.” Economic Journal 105 (September 1995), 1110-1129.

Hinz, Richard P., David D. McCarthy, and John A. Turner. "Are Women Conservative Investors? Gender Differences in Participant Directed Pension Investments," in Michael S. Gordon, Olivia S. Mitchell, and Marc M. Twinney, eds., Positioning Pensions for the TwentyFirst Century. Philadelphia: University of Pennsylvania Press, 1997, 91-103.

Jason, Julie. The 401(k) Plan Handbook. Englewood Cliffs, NJ: Prentice Hall, 1997.

Katona, George. "Private Pensions and Individual Savings." Ann Arbor, MI: Survey Research Center, Institute for Social Research, University of Michigan, 1965.

Kennickell, Arthur. Codebookfor 1995 Survey of Consumer Finances. Washington, D. C., 1997.

King, Mervyn A. and Jonathan I. Leape. "Asset Accumulation, Information, and the Life Cycle." NBER working Paper No. 2392. Cambridge, MA: National Bureau of Economic Research, 1987.

O’Donoghue, Ted and Matthew Rabin. "Doing It Now or Later." American Economic Review 89(1) (March 1999), 103-24.

Papke, Leslie E. "How Are Participants Investing Their Accounts in Participant-Directed Individual Account Pension Plans?" AEA Papers and Proceedings 88 (May 1998), 212-216. 
Poterba, James and Andrew Samwick. "Household Portfolio Allocation Over the Life Cycle." NBER working Paper No. 6185. Cambridge, MA: National Bureau of Economic Research, 1997.

Poterba, James, Steven Venti, and David Wise. "How Retirement Saving Programs Increase Saving." Journal of Economic Perspectives 10 (Fall 1996), 91-112.

Siegel, Jeremy J. and Richard M. Thaler. "The Equity Premium Puzzle.” Journal of Economic Perspectives 11 (Winter 1997), 191-200.

Sunden, Annika E. and Brian J. Surette. "Gender Differences in the Allocation of Assets in Retirement Savings Plans.” American Economic Review 88(2) (May 1998), 207-211.

Thaler, Richard H. "Psychology and Savings Policies." AEA Papers and Proceedings (May 1994), 186-192.

Thaler, Richard H. and Hersh M. Shefrin. "An Economic Theory of Self-Control." Journal of Political Economy 89 (April 1981), 392-406.

U. S. Department of Labor. Private Pension Plan Bulletin No. 6 (Winter 1997).

U. S. Government Accounting Office. "401(k) Pension Plans: Extent of Plans' Investments in Employer Securities and Real Property.” GAO/GGD-98-23. Washington, D. C.: General Accounting Office, November 1997. 


\section{Table 1: Income, Net Worth, \& Demographics of Households with Various Pension Plan Coverage}

\begin{tabular}{|c|c|c|c|c|}
\hline & $\begin{array}{l}\text { Have DC Plan(s) } \\
\text { (at least one } \\
\text { with CHOICE) }\end{array}$ & $\begin{array}{l}\text { Have DC Plan(s) } \\
\text { (none have } \\
\text { CHOICE) }\end{array}$ & $\begin{array}{l}\text { Only } 1 \text { Pension Plan } \\
\text { (is a DC plan } \\
\text { with CHOICE) }\end{array}$ & $\begin{array}{l}\text { Only } 1 \text { Pension Plan } \\
\text { (is a DC plan } \\
\text { without CHOICE) }\end{array}$ \\
\hline \# observations & 779 & 272 & 344 & 174 \\
\hline \multirow[t]{2}{*}{ \# households } & 19.8 million & 7.1 million & 8.9 million & 4.6 million \\
\hline & \multicolumn{4}{|c|}{$\begin{array}{l}\text { Income \& Net Worth (in thousands of \$) } \\
\text { (the mean, with its standard error in parentheses, and the } 25^{\text {th }} \& 75^{\text {th }} \% \text { are reported) }\end{array}$} \\
\hline $\begin{array}{c}\text { Income } \\
25^{\text {th }}-75^{\text {th }} \%\end{array}$ & $\begin{array}{c}65.0 \\
(3.4) \\
35-74\end{array}$ & $\begin{array}{c}45.2 \\
(2.3) \\
26-57\end{array}$ & $\begin{array}{c}54.8 \\
(5.7) \\
30-60\end{array}$ & $\begin{array}{c}41.3 \\
(3.0) \\
22-50\end{array}$ \\
\hline $\begin{array}{l}\text { Net Worth } \\
25^{\text {th }}-75^{\text {th }} \%\end{array}$ & $\begin{array}{c}155.0 \\
(21.5) \\
18-134\end{array}$ & $\begin{array}{c}96.5 \\
(17.8) \\
12-98\end{array}$ & $\begin{array}{c}142.6 \\
(38.2) \\
14-113\end{array}$ & $\begin{array}{c}78.3 \\
(23.9) \\
8.5-79\end{array}$ \\
\hline $\begin{array}{l}\text { Financial Assets } \\
25^{\text {th }}-75^{\text {th }} \%\end{array}$ & $\begin{array}{c}71.2 \\
(15.0) \\
3.1-49\end{array}$ & $\begin{array}{c}34.4 \\
(11.8) \\
1.4-23\end{array}$ & $\begin{array}{c}66.1 \\
(26.7) \\
2.1-29\end{array}$ & $\begin{array}{c}26.7 \\
(16.9) \\
1.1-18\end{array}$ \\
\hline $25^{\text {th }}-75^{\text {th }} \%$ & \multicolumn{4}{|c|}{ Equity Ownership Outside of the Pension Plan } \\
\hline $\begin{array}{c}\text { Probability } \\
\text { own stock }>\$ 1000\end{array}$ & $\begin{array}{l}.39 \\
(.02)\end{array}$ & $\begin{array}{l}.16 \\
(.02)\end{array}$ & $\begin{array}{l}.33 \\
(.03)\end{array}$ & $\begin{array}{l}.12 \\
(.02)\end{array}$ \\
\hline $\begin{array}{l}\text { Ratio of stock } \\
\text { holdings to total } \\
\text { financial assets }\end{array}$ & $\begin{array}{l}.20 \\
(.01)\end{array}$ & $\begin{array}{l}.10 \\
(.01)\end{array}$ & $\begin{array}{l}.18 \\
(.02)\end{array}$ & $\begin{array}{l}.08 \\
(.02)\end{array}$ \\
\hline \multirow[t]{2}{*}{$\begin{array}{l}\text { Stock/Fin given } \\
\text { own stock }\end{array}$} & $\begin{array}{l}.45 \\
(.01)\end{array}$ & $\begin{array}{l}.41 \\
(.04)\end{array}$ & $\begin{array}{l}.48 \\
(.02)\end{array}$ & $\begin{array}{l}.42 \\
(.05)\end{array}$ \\
\hline & \multicolumn{4}{|c|}{ Demographics } \\
\hline Age & $\begin{array}{l}41.3 \\
(.4)\end{array}$ & $\begin{array}{l}40.6 \\
(.6)\end{array}$ & $\begin{array}{l}40.6 \\
(.6)\end{array}$ & $\begin{array}{l}39.5 \\
(.7)\end{array}$ \\
\hline Married & $\begin{array}{c}.74 \\
(.02)\end{array}$ & $\begin{array}{c}.73 \\
(.03)\end{array}$ & $\begin{array}{c}.64 \\
(.03)\end{array}$ & $\begin{array}{c}.67 \\
(.04)\end{array}$ \\
\hline Female & $\begin{array}{c}.17 \\
(.01)\end{array}$ & $\begin{array}{c}.19 \\
(.02)\end{array}$ & $\begin{array}{c}.24 \\
(.02)\end{array}$ & $\begin{array}{l}.22 \\
(.03)\end{array}$ \\
\hline College & $\begin{array}{c}.47 \\
(.02)\end{array}$ & $\begin{array}{c}.39 \\
(.03)\end{array}$ & $\begin{array}{c}.41 \\
(.03)\end{array}$ & $\begin{array}{l}.37 \\
(.04)\end{array}$ \\
\hline
\end{tabular}

Data source is the 1995 Survey of Consumer Finances and reported statistics are weighted to reflect the population. See text for variable definitions.

CHOICE refers to a pension plan in which the employee makes investment decisions.

The mean is reported for all variables and the standard error of the mean is in parentheses.

"Stock/Fin" is the average of the ratio of non-pension stock holdings to financial assets. 
Table 1 (continued): Retirement Plan Assets and Saving Preferences of Households with Various Pension Plan Coverage

\begin{tabular}{|c|c|c|c|c|}
\hline & $\begin{array}{l}\text { Have DC Plan(s) } \\
\text { (at least one } \\
\text { with CHOICE) }\end{array}$ & $\begin{array}{c}\text { Have DC Plan (s) } \\
\text { (none have } \\
\text { CHOICE) }\end{array}$ & $\begin{array}{l}\text { Only } 1 \text { Pension Plan } \\
\text { (is a DC plan } \\
\text { with CHOICE) }\end{array}$ & $\begin{array}{l}\text { Only } 1 \text { Pension Plan } \\
\text { (is a DC plan } \\
\text { without CHOICE) }\end{array}$ \\
\hline \# observations & 779 & 272 & 344 & 174 \\
\hline \# households & 19.8 million & 7.1 million & 8.9 million & 4.6 million \\
\hline $\begin{array}{c}\text { DC Plan Assets } \\
25^{\text {th }}-75^{\text {th }} \%\end{array}$ & $\begin{array}{c}38.6 \\
(4.7) \\
3.1-38\end{array}$ & $\begin{array}{c}16.8 \\
(2.0) \\
1.6-20\end{array}$ & $\begin{array}{c}18.7 \\
(3.6) \\
2.2-20\end{array}$ & $\begin{array}{c}12.2 \\
(1.6) \\
1.3-12\end{array}$ \\
\hline $\begin{array}{l}\text { Share of DC plan } \\
\text { in stock }\end{array}$ & $\begin{array}{l}.60 \\
(.01)\end{array}$ & $\begin{array}{l}.53 \\
(.02)\end{array}$ & $\begin{array}{l}.57 \\
(.02)\end{array}$ & $\begin{array}{l}.49 \\
(.03)\end{array}$ \\
\hline $\begin{array}{l}\% \text { DC plans mostly } \\
\text { or all stock }\end{array}$ & $\begin{array}{l}.32 \\
(.02)\end{array}$ & $\begin{array}{l}.33 \\
(.03)\end{array}$ & $\begin{array}{l}.38 \\
(.03)\end{array}$ & $\begin{array}{l}.31 \\
(.04)\end{array}$ \\
\hline \# Pension Plans & $\begin{array}{l}1.8 \\
(.03)\end{array}$ & $\begin{array}{l}1.4 \\
(.04)\end{array}$ & 1 & 1 \\
\hline Have DB Plan? & $\begin{array}{l}.31 \\
(.02)\end{array}$ & $\begin{array}{l}.25 \\
(.03)\end{array}$ & 0 & 0 \\
\hline $\begin{array}{l}\text { IRA Assets } \\
25^{\text {th }}-75^{\text {th }} \%\end{array}$ & $\begin{array}{c}42.6 \\
(9.9) \\
5.0-38\end{array}$ & $\begin{array}{c}20.8 \\
(7.3) \\
3.0-20\end{array}$ & $\begin{array}{c}50.9 \\
(22.0) \\
4.0-30\end{array}$ & $\begin{array}{c}19.4 \\
(10.7) \\
3.0-20\end{array}$ \\
\hline $\begin{array}{l}\text { Share of IRA } \\
\text { in stock }\end{array}$ & $\begin{array}{l}.57 \\
(.03)\end{array}$ & $\begin{array}{l}.31 \\
(.05)\end{array}$ & $\begin{array}{l}.58 \\
(.04)\end{array}$ & $\begin{array}{l}.21 \\
(.06)\end{array}$ \\
\hline Have IRA? & $\begin{array}{l}.36 \\
(.02)\end{array}$ & $\begin{array}{l}.24 \\
(.03)\end{array}$ & $\begin{array}{l}.34 \\
(.03)\end{array}$ & $\begin{array}{l}.25 \\
(.03)\end{array}$ \\
\hline Love Risk? & $\begin{array}{l}.29 \\
(.02)\end{array}$ & $\begin{array}{l}.16 \\
(.02)\end{array}$ & $\begin{array}{l}.29 \\
(.02)\end{array}$ & $\begin{array}{l}.17 \\
(.03)\end{array}$ \\
\hline Hate Risk? & $\begin{array}{l}.23 \\
(.01)\end{array}$ & $\begin{array}{l}.39 \\
(.03)\end{array}$ & $\begin{array}{l}.25 \\
(.02)\end{array}$ & $\begin{array}{l}.39 \\
(.04)\end{array}$ \\
\hline NOSAVER? & $\begin{array}{l}.48 \\
(.02)\end{array}$ & $\begin{array}{l}.65 \\
(.03)\end{array}$ & $\begin{array}{l}.50 \\
(.03)\end{array}$ & $\begin{array}{l}.63 \\
(.04)\end{array}$ \\
\hline
\end{tabular}

See text for variable definitions.

CHOICE refers to a pension plan in which the employee makes investment decisions.

DC plan assets and IRA assets are in thousands of dollars.

IRA assets are reported conditional on ownership.

The mean is reported for all variables and the standard error of the mean is in parentheses. 
Table 2: Regressions of equity ownership outside of DC plan

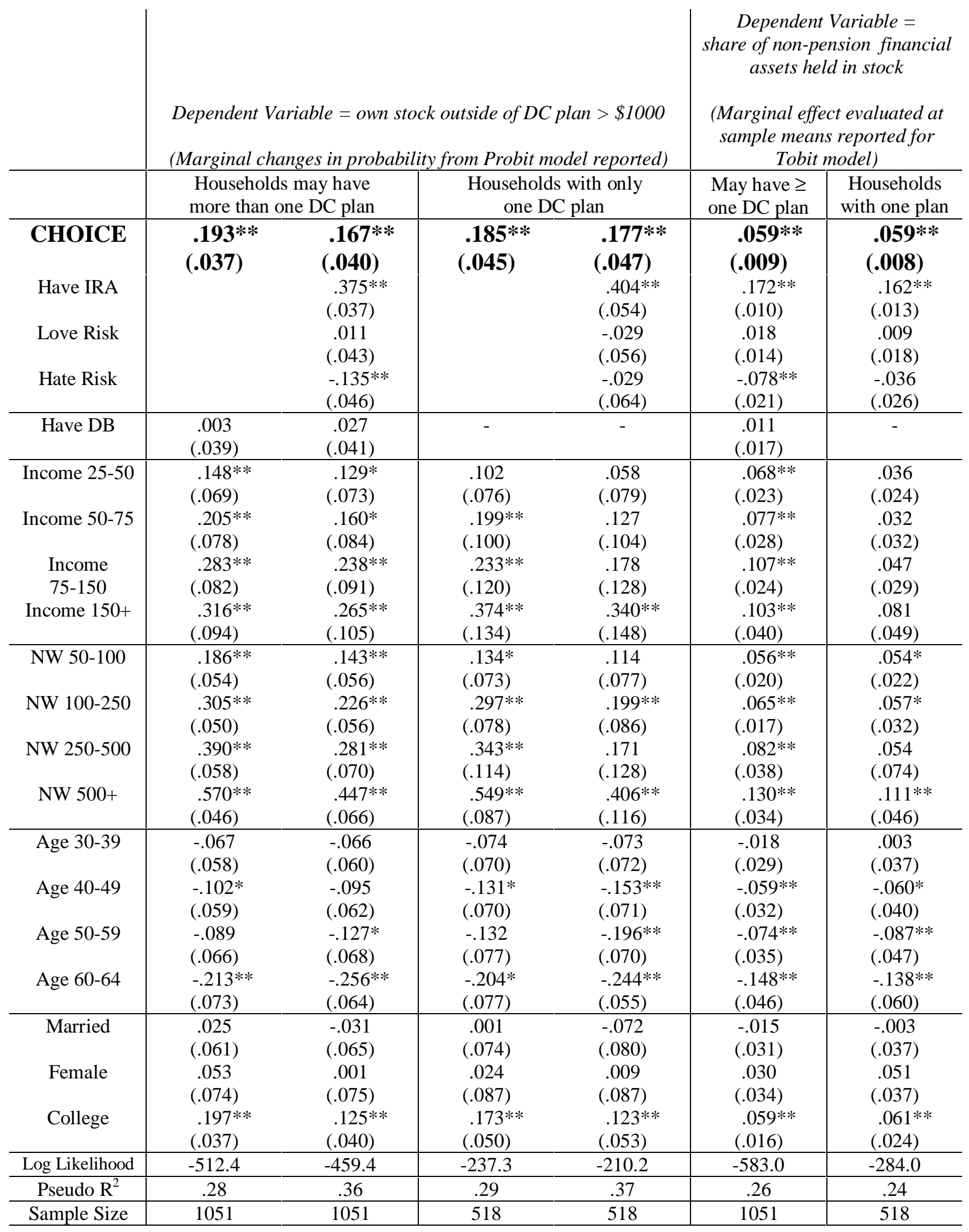


Notes:

All regressors are indicator variables, so the marginal effect of variable $i$ in the Probit model is estimated by $\Phi\left(X_{-i} \beta_{-i}+\beta_{i}\right)-\Phi\left(X_{-i} \beta_{-i}\right)$ where $\beta_{i}$ is the Probit coefficient corresponding to variable $i$ and $X_{-i}$ and $\beta_{-i}$ are vectors of regressor means and the corresponding Probit coefficients excluding variable $i$. This transformation is done to all Probit coefficients in subsequent tables. The full sample is all households covered by at least one DC plan (may have multiple DC plans and a DB plan). The "households with only one plan" sample is restricted to households covered by only one pension plan that is a DC plan.

$\mathrm{CHOICE}=1$ if the household participates in a plan where they choose investments.

$* *=$ underlying coefficient is statistically significant at $5 \%$ level

$*=$ underlying coefficient is statistically significant at $10 \%$ level 
Table 3: Income, Net Worth, \& Demographics of NOSAVERS with Various Pension Plans

\begin{tabular}{|c|c|c|c|c|}
\hline & $\begin{array}{l}\text { Have DC Plan(s) } \\
\text { (at least one } \\
\text { with CHOICE) }\end{array}$ & $\begin{array}{l}\text { Have DC Plan(s) } \\
\text { (none have } \\
\text { CHOICE) }\end{array}$ & $\begin{array}{l}\text { Only } 1 \text { Pension Plan } \\
\text { (is a DC plan } \\
\text { with CHOICE) }\end{array}$ & $\begin{array}{l}\text { Only } 1 \text { Pension Plan } \\
\text { (is a DC plan } \\
\text { without CHOICE) }\end{array}$ \\
\hline \# observations & 313 & 162 & 145 & 102 \\
\hline \multirow[t]{2}{*}{ \# households } & 9.5 million & 4.6 million & 4.4 million & 2.9 million \\
\hline & \multicolumn{4}{|c|}{$\begin{array}{l}\text { Income \& Net Worth (in thousands of \$) } \\
\text { (the mean, with its standard error in parentheses, and the } 25^{\text {th }} \& 75^{\text {th }} \% \text { are reported) }\end{array}$} \\
\hline $\begin{array}{c}\text { Income } \\
25^{\text {th }}-75^{\text {th }} \%\end{array}$ & $\begin{array}{c}49.5 \\
(2.1) \\
30-60\end{array}$ & $\begin{array}{c}40.3 \\
(2.6) \\
22-51\end{array}$ & $\begin{array}{c}40.0 \\
(1.5) \\
27-47\end{array}$ & $\begin{array}{c}35.6 \\
(3.6) \\
20-44\end{array}$ \\
\hline $\begin{array}{l}\text { Net Worth } \\
25^{\text {th }}-75^{\text {th }} \%\end{array}$ & $\begin{array}{c}71.4 \\
(16.0) \\
11-86\end{array}$ & $\begin{array}{c}61.0 \\
(15.8) \\
8.7-67\end{array}$ & $\begin{array}{c}65.3 \\
(33.6) \\
6.2-71\end{array}$ & $\begin{array}{c}46.4 \\
(20.4) \\
6.8-58\end{array}$ \\
\hline $\begin{array}{l}\text { Financial Assets } \\
\qquad 25^{\text {th }}-75^{\text {th }} \%\end{array}$ & $\begin{array}{c}27.3 \\
(15.6) \\
1.4-19\end{array}$ & $\begin{array}{c}16.0 \\
(8.6) \\
1.0-14\end{array}$ & $\begin{array}{c}27.6 \\
(33.4) \\
1.1-12\end{array}$ & $\begin{array}{l}10.5 \\
(11.8) \\
.8-11\end{array}$ \\
\hline $25^{\text {th }}-75^{\text {th }} \%$ & \multicolumn{4}{|c|}{ Equity Ownership Outside of the Pension Plan } \\
\hline $\begin{array}{c}\text { Probability } \\
\text { own stock }>\$ 1000\end{array}$ & $\begin{array}{l}.17 \\
(.02)\end{array}$ & .07 & $\begin{array}{l}.14 \\
(.03)\end{array}$ & $\begin{array}{l}.05 \\
(.02)\end{array}$ \\
\hline $\begin{array}{l}\text { Ratio of stock } \\
\text { holdings to total } \\
\text { financial assets }\end{array}$ & $\begin{array}{l}.10 \\
(.01)\end{array}$ & $\begin{array}{l}.04 \\
(.01)\end{array}$ & $\begin{array}{l}.09 \\
(.02)\end{array}$ & $\begin{array}{l}.03 \\
(.01)\end{array}$ \\
\hline \multirow[t]{2}{*}{$\begin{array}{l}\text { Stock/Fin given } \\
\text { own stock }\end{array}$} & $\begin{array}{l}.42 \\
(.04)\end{array}$ & $\begin{array}{l}.32 \\
(.06)\end{array}$ & $\begin{array}{l}.46 \\
(.06)\end{array}$ & $\begin{array}{l}.32 \\
(.07)\end{array}$ \\
\hline & \multicolumn{4}{|c|}{ Demographics } \\
\hline Age & $\begin{array}{l}40.6 \\
(.6)\end{array}$ & $\begin{array}{l}40.0 \\
(.8)\end{array}$ & $\begin{array}{l}39.5 \\
(.8)\end{array}$ & $\begin{array}{l}38.9 \\
(.9)\end{array}$ \\
\hline Married & $\begin{array}{l}.70 \\
(.03)\end{array}$ & $\begin{array}{c}.69 \\
(.04)\end{array}$ & $\begin{array}{c}.60 \\
(.04)\end{array}$ & $\begin{array}{c}.61 \\
(.05)\end{array}$ \\
\hline Female & $\begin{array}{l}.19 \\
(.02)\end{array}$ & $\begin{array}{l}.21 \\
(.03)\end{array}$ & $\begin{array}{l}.27 \\
(.04)\end{array}$ & $\begin{array}{l}.27 \\
(.04)\end{array}$ \\
\hline College & $\begin{array}{c}.31 \\
(.03)\end{array}$ & $\begin{array}{c}.35 \\
(.04)\end{array}$ & $\begin{array}{c}.28 \\
(.04)\end{array}$ & $\begin{array}{c}.32 \\
(.05)\end{array}$ \\
\hline
\end{tabular}

Data source is the 1995 Survey of Consumer Finances and reported statistics are weighted to reflect the population. See text for variable definitions.

CHOICE refers to a pension plan in which the employee makes investment decisions. A household is a NOSAVER if it has no IRA assets and does not report it is willing to take above average risks to earn above average returns.

The mean is reported for all variables and the standard error of the mean is in parentheses. "Stock/Fin" is the average of the ratio of non-pension stock holdings to financial assets. 


\section{Table 3 (continued): Retirement Plan Assets and Saving Preferences for NOSAVER with Various Pension Plans}

\begin{tabular}{|c|c|c|c|c|}
\hline & $\begin{array}{l}\text { Have DC Plan(s) } \\
\text { (at least one } \\
\text { with CHOICE) }\end{array}$ & $\begin{array}{l}\text { Have DC Plan(s) } \\
\text { (none have } \\
\text { CHOICE) }\end{array}$ & $\begin{array}{l}\text { Only } 1 \text { Pension Plan } \\
\text { (is a DC plan } \\
\text { with CHOICE) }\end{array}$ & $\begin{array}{c}\text { Only } 1 \text { Pension Plan } \\
\text { (is a DC plan } \\
\text { without CHOICE) }\end{array}$ \\
\hline \# observations & 313 & 162 & 145 & 102 \\
\hline \# households & 9.5 million & 4.6 million & 4.4 million & 2.9 million \\
\hline $\begin{array}{c}\text { DC Plan Assets } \\
25^{\text {th }}-75^{\text {th }} \%\end{array}$ & $\begin{array}{c}24.8 \\
(2.8) \\
2.5-30\end{array}$ & $\begin{array}{c}15.7 \\
(2.5) \\
1.7-20\end{array}$ & $\begin{array}{c}12.2 \\
(1.3) \\
2.0-15\end{array}$ & $\begin{array}{c}10.4 \\
(1.6) \\
1.2-12\end{array}$ \\
\hline $\begin{array}{l}\text { Share of plan } \\
\text { in stock }\end{array}$ & $\begin{array}{l}.55 \\
(.02)\end{array}$ & $\begin{array}{l}.52 \\
(.03)\end{array}$ & $\begin{array}{l}.51 \\
(.03)\end{array}$ & $\begin{array}{l}.49 \\
(.04)\end{array}$ \\
\hline $\begin{array}{l}\% \text { plans mostly or } \\
\text { all stock }\end{array}$ & $\begin{array}{l}.24 \\
(.02)\end{array}$ & $\begin{array}{l}.30 \\
(.04)\end{array}$ & $\begin{array}{l}.29 \\
(.04)\end{array}$ & $\begin{array}{l}.29 \\
(.05)\end{array}$ \\
\hline \# Pension Plans & $\begin{array}{l}1.8 \\
(.05)\end{array}$ & $\begin{array}{l}1.5 \\
(.05)\end{array}$ & 1 & 1 \\
\hline Have DB Plan? & $\begin{array}{l}.29 \\
(.03)\end{array}$ & $\begin{array}{l}.25 \\
(.03)\end{array}$ & 0 & 0 \\
\hline $\begin{array}{l}\text { IRA Assets } \\
25^{\text {th }}-75^{\text {th }} \%\end{array}$ & - & - & - & - \\
\hline $\begin{array}{l}\text { Share of IRA } \\
\text { in stock }\end{array}$ & - & - & - & - \\
\hline Have IRA? & 0 & 0 & 0 & 0 \\
\hline Love Risk? & 0 & 0 & 0 & 0 \\
\hline Hate Risk? & $\begin{array}{l}.38 \\
(.03)\end{array}$ & $\begin{array}{l}.51 \\
(.04)\end{array}$ & $\begin{array}{l}.40 \\
(.04)\end{array}$ & $\begin{array}{l}.52 \\
(.05)\end{array}$ \\
\hline NOSAVER? & 1 & 1 & 1 & 1 \\
\hline
\end{tabular}

See text for variable definitions.

CHOICE refers to a pension plan in which the employee makes investment decisions.

DC plan assets are in thousands of dollars.

The mean is reported for all variables and the standard error of the mean is in parentheses. 
Table 4: Regressions of equity ownership outside of DC plan for "NOSAVERS" (NOSAVERS have no IRA assets and are not willing to take above average risks)

Dependent Variable $=$ own stock outside of DC plan $>\$ 1000$

Marginal changes in probability from Probit model reported

\begin{tabular}{|c|c|c|}
\hline & May have $\geq$ one DC plan & Households with one DC plan \\
\hline CHOICE & $\begin{array}{l}.077 * * \\
(.031)\end{array}$ & $\begin{array}{l}.072 * \\
(.037)\end{array}$ \\
\hline Have IRA & - & - \\
\hline Love Risk & - & - \\
\hline Hate Risk & $\begin{array}{r}-.032 \\
(.033) \\
\end{array}$ & $\begin{array}{r}.008 \\
(.038) \\
\end{array}$ \\
\hline Have DB & $\begin{array}{l}-.002 \\
(.035) \\
\end{array}$ & - \\
\hline Income $25-50$ & $\begin{array}{l}.098 * \\
(.056)\end{array}$ & $\begin{array}{l}.065 \\
(.052)\end{array}$ \\
\hline Income $50-75$ & $\begin{array}{l}.135^{*} \\
(.087)\end{array}$ & $\begin{array}{l}.172 * \\
(.120)\end{array}$ \\
\hline Income $75-150$ & $\begin{array}{l}.262^{* *} \\
(.124)\end{array}$ & $\begin{array}{l}.170 \\
(.168)\end{array}$ \\
\hline Income $150+$ & $\begin{array}{l}.088 \\
(.149) \\
\end{array}$ & $\begin{array}{c}.330 \\
(.341)\end{array}$ \\
\hline Net Worth 50-100 & $\begin{array}{l}.133^{* *} \\
(.057)\end{array}$ & $\begin{array}{c}.088 \\
(.065)\end{array}$ \\
\hline Net Worth $100-250$ & $\begin{array}{l}.204 * * \\
(.068)\end{array}$ & $\begin{array}{l}.151^{*} \\
(.100)\end{array}$ \\
\hline Net Worth 250-500 & $\begin{array}{l}.400^{* *} \\
(.131)\end{array}$ & $\begin{array}{l}.272 \\
(.334)\end{array}$ \\
\hline Net Worth $500+$ & $\begin{array}{l}.532^{* *} \\
(.159)\end{array}$ & $\begin{array}{l}.433^{* *} \\
(.236)\end{array}$ \\
\hline Age 30-39 & $\begin{array}{l}-.027 \\
(.045)\end{array}$ & $\begin{array}{l}-.005 \\
(.050)\end{array}$ \\
\hline Age $40-49$ & $\begin{array}{l}-.091 * \\
(.043)\end{array}$ & $\begin{array}{l}-.097 * \\
(.044)\end{array}$ \\
\hline Age 50-59 & $\begin{array}{l}-.079 \\
(.039)\end{array}$ & $\begin{array}{l}-.056 \\
(.045)\end{array}$ \\
\hline Age 60-64 & $\begin{array}{l}-.089 \\
(.041) \\
\end{array}$ & $\begin{array}{l}-.067 \\
(.052) \\
\end{array}$ \\
\hline Married & $\begin{array}{l}.041 \\
(.050)\end{array}$ & $\begin{array}{l}.016 \\
(.056)\end{array}$ \\
\hline Female & $\begin{array}{l}.075 \\
(.082)\end{array}$ & $\begin{array}{c}.059 \\
(.080)\end{array}$ \\
\hline College & $\begin{array}{l}.072 * * \\
(.038)\end{array}$ & $\begin{array}{l}.067 \\
(.049) \\
\end{array}$ \\
\hline Log Likelihood & -173.7 & -77.2 \\
\hline Pseudo $\mathrm{R}^{2}$ & .18 & .17 \\
\hline Sample Size & 475 & 247 \\
\hline
\end{tabular}

In the left panel, the sample is all households with at least one DC plan (may have multiple plans and DB plan). In the right panel, the sample is restricted to households covered by only one pension plan that is a DC plan.

$\mathrm{CHOICE}=1$ if the household participates in a plan in which they choose investments.

$* *=$ underlying Probit coefficient is statistically significant at $5 \%$ level, $*=$ coefficient is significant at $10 \%$ level 


\section{Table 5: Regressions of equity ownership outside of DC plan (DC plan must be a 401(k) / 403(b))}

Dependent Variable $=$ own stock outside of 401 $(k)$ plan $>\$ 1000$ Marginal changes in probability from Probit model reported

\begin{tabular}{|c|c|c|c|c|}
\hline & \multicolumn{2}{|c|}{ May have more than one $401(\mathrm{k})$ plan } & \multicolumn{2}{|c|}{ Households with only one $401(\mathrm{k})$ plan } \\
\hline & Full Sample & NOSAVERS & Full Sample & NOSAVERS \\
\hline CHOICE & $\begin{array}{l}.274 * * \\
(.055)\end{array}$ & $\begin{array}{l}.135 * * \\
(.032)\end{array}$ & $\begin{array}{l}.227 * * \\
(.061)\end{array}$ & $\begin{array}{l}.115 * \\
(.037)\end{array}$ \\
\hline Have IRA & $\begin{array}{l}.428 * * \\
(.049)\end{array}$ & - & $\begin{array}{l}.442 * * \\
(.062)\end{array}$ & - \\
\hline Love Risk & $\begin{array}{l}.027 \\
(.058)\end{array}$ & - & $\begin{array}{l}.019 \\
(.070)\end{array}$ & - \\
\hline Hate Risk & $\begin{array}{l}-.178 * * \\
(.064) \\
\end{array}$ & $\begin{array}{l}-.040 \\
(.033)\end{array}$ & $\begin{array}{l}-.104 \\
(.078)\end{array}$ & $\begin{array}{l}-.029 \\
(.035)\end{array}$ \\
\hline Have DB & $\begin{array}{l}.091 \\
(.059) \\
\end{array}$ & $\begin{array}{l}.000 \\
(.038) \\
\end{array}$ & - & - \\
\hline Income $25-50$ & $\begin{array}{l}.225^{* *} \\
(.101)\end{array}$ & $\begin{array}{l}.138^{*} \\
(.073)\end{array}$ & $\begin{array}{l}.170 \\
(.107)\end{array}$ & $\begin{array}{c}.096 \\
(.063)\end{array}$ \\
\hline Income $50-75$ & $\begin{array}{l}.203 * \\
(.117)\end{array}$ & $\begin{array}{l}.179 \\
(.152)\end{array}$ & $\begin{array}{l}.148 \\
(.138)\end{array}$ & $\begin{array}{l}.159 \\
(.174)\end{array}$ \\
\hline Income & $.260 * *$ & $.308^{* *}$ & .199 & .262 \\
\hline $75-150$ & $(.124)$ & $(.208)$ & $(.158)$ & $(.259)$ \\
\hline Income $150+$ & $\begin{array}{l}.325 * * \\
(.141) \\
\end{array}$ & $\begin{array}{l}.473 * \\
(.321)\end{array}$ & $\begin{array}{l}.319 * \\
(.187)\end{array}$ & $\begin{array}{l}.605 \\
(.448)\end{array}$ \\
\hline NW 50-100 & $\begin{array}{l}.162 * * \\
(.079)\end{array}$ & $\begin{array}{l}.076 \\
(.063)\end{array}$ & $\begin{array}{c}.081 \\
(.098)\end{array}$ & $\begin{array}{l}.015 \\
(.052)\end{array}$ \\
\hline NW $100-250$ & $\begin{array}{l}.140^{*} \\
(.077)\end{array}$ & $\begin{array}{l}.101^{*} \\
(.076)\end{array}$ & $\begin{array}{l}.180 * \\
(.103)\end{array}$ & $\begin{array}{l}.025 \\
(.069)\end{array}$ \\
\hline NW 250-500 & $\begin{array}{l}.096 \\
(.108)\end{array}$ & $\begin{array}{l}.360 * * \\
(.234)\end{array}$ & $\begin{array}{l}.107 \\
(.148)\end{array}$ & $\begin{array}{l}.348 \\
(.454)\end{array}$ \\
\hline NW 500+ & $\begin{array}{l}.364 * * \\
(.110)\end{array}$ & $\begin{array}{l}.171 \\
(.241)\end{array}$ & $\begin{array}{l}.362^{* * *} \\
(.157)\end{array}$ & $\begin{array}{r}.164 \\
(.300) \\
\end{array}$ \\
\hline Age 30-39 & $\begin{array}{l}-.129 \\
(.077)\end{array}$ & $\begin{array}{l}-.050 \\
(.038)\end{array}$ & $\begin{array}{l}-.035 \\
(.091)\end{array}$ & $\begin{array}{l}.005 \\
(.049)\end{array}$ \\
\hline Age $40-49$ & $\begin{array}{l}-.167 * * \\
(.079)\end{array}$ & $\begin{array}{l}-.095^{* *} \\
(.041)\end{array}$ & $\begin{array}{l}-.157 * \\
(.087)\end{array}$ & $\begin{array}{l}-.037 \\
(.046)\end{array}$ \\
\hline Age $50-59$ & $\begin{array}{l}-.112 \\
(.093)\end{array}$ & $\begin{array}{l}-.037 \\
(.045)\end{array}$ & $\begin{array}{l}-.133 \\
(.100)\end{array}$ & $\begin{array}{l}.020 \\
(.081)\end{array}$ \\
\hline Age $60-64$ & $\begin{array}{l}-.250 * * \\
(.090)\end{array}$ & $\begin{array}{l}-.063 \\
(.031)\end{array}$ & $\begin{array}{l}-.256^{* *} \\
(.070)\end{array}$ & - \\
\hline Married & $\begin{array}{l}-.021 \\
(.091)\end{array}$ & $\begin{array}{c}.011 \\
(.054)\end{array}$ & $\begin{array}{l}-.018 \\
(.105)\end{array}$ & $\begin{array}{l}-.009 \\
(.064)\end{array}$ \\
\hline Female & $\begin{array}{l}-.005 \\
(.102)\end{array}$ & $\begin{array}{l}.001 \\
(.068)\end{array}$ & $\begin{array}{l}.051 \\
(.119)\end{array}$ & $\begin{array}{l}.003 \\
(.066)\end{array}$ \\
\hline College & $\begin{array}{l}.154 * * \\
(.055)\end{array}$ & $\begin{array}{l}.052 \\
(.043) \\
\end{array}$ & $\begin{array}{l}.127 * \\
(.067) \\
\end{array}$ & $\begin{array}{l}.042 \\
(.049) \\
\end{array}$ \\
\hline Log Likelihood & -239.7 & -76.9 & -141.0 & -44.1 \\
\hline Pseudo $\mathrm{R}^{2}$ & .36 & .22 & .36 & .20 \\
\hline Sample Size & 551 & 233 & 337 & 152 \\
\hline
\end{tabular}


Table 6: Regressions of equity ownership outside of DC plan (controls for \% of DC plan invested in stock \& size of DC plan relative to non-pension financial assets)

Dependent Variable $=$ own stock outside of DC plan $>\$ 1000$ Marginal changes in probability from Probit model reported May have more than one DC plan Households with only one DC plan

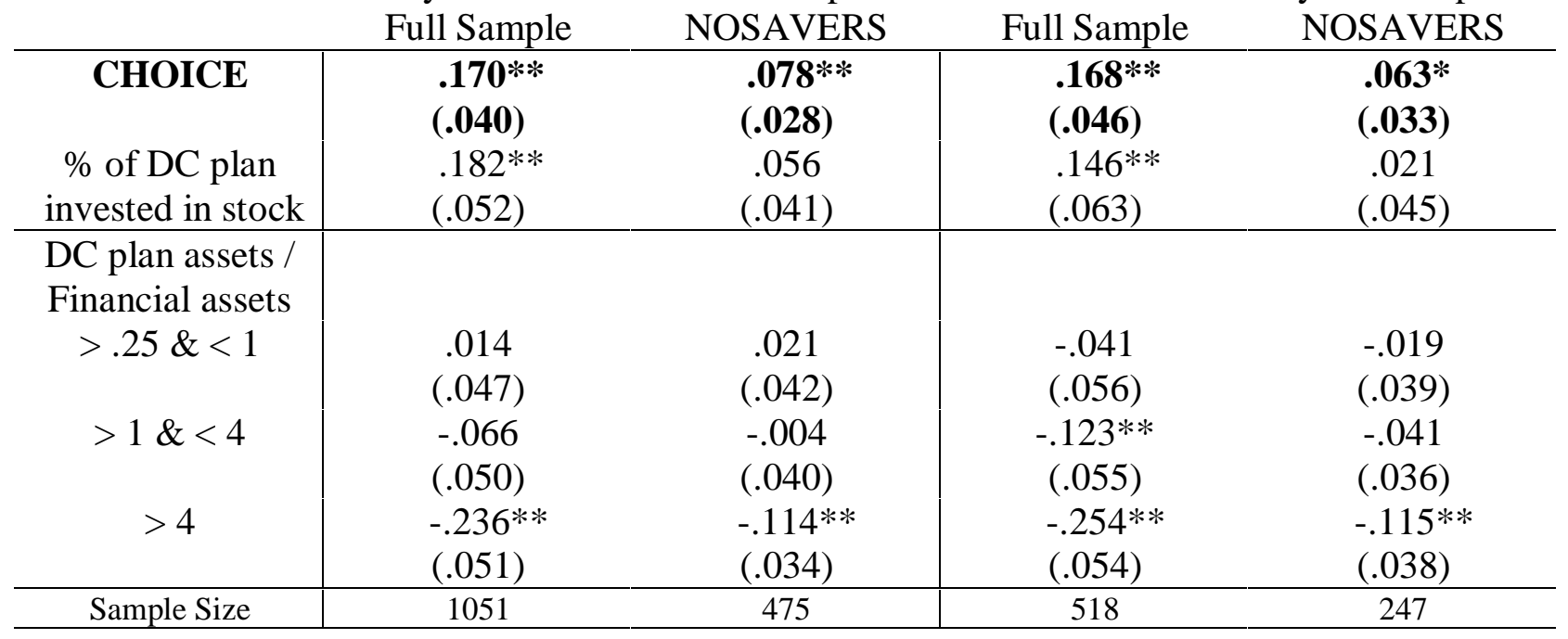

\section{HOUSEHOLD MUST HAVE NON-PENSION FINANCIAL ASSETS > \$20K}

Dependent Variable $=$ own stock outside of DC plan $>\$ 1000$

Marginal changes in probability from Probit model reported

May have more than one plan Households with only one plan

\begin{tabular}{|c|c|c|c|c|}
\hline & Full Sample & NOSAVERS & Full Sample & NOSAVERS \\
\hline $\begin{array}{c}\text { CHOICE } \\
\text { \% of DC plan } \\
\text { invested in stock }\end{array}$ & $\begin{array}{l}\mathbf{. 1 6 9} * * \\
\mathbf{( . 0 5 8 )} \\
.206 * * \\
(.063)\end{array}$ & $\begin{array}{l}\mathbf{. 1 6 1} * * \\
\mathbf{( . 0 6 0 )} \\
.133 \\
(.094)\end{array}$ & $\begin{array}{l}\mathbf{. 1 8 8} * * \\
(.086) \\
.260 * * \\
(.102)\end{array}$ & $\begin{array}{c}\mathbf{0 8 3} \\
(.109) \\
.118 \\
(.151)\end{array}$ \\
\hline $\begin{array}{l}\text { DC plan assets / } \\
\text { Financial assets }\end{array}$ & & & & \\
\hline$>.25 \&<1$ & $\begin{array}{c}.093 \\
(.056)\end{array}$ & $\begin{array}{l}.118 \\
(.101)\end{array}$ & $\begin{array}{c}.072 \\
(.093)\end{array}$ & $\begin{array}{l}.197 \\
(.192)\end{array}$ \\
\hline$>1 \&<4$ & $\begin{array}{c}.006 \\
(.064)\end{array}$ & $\begin{array}{c}.085 \\
(.099)\end{array}$ & $\begin{array}{c}.007 \\
(.114)\end{array}$ & $\begin{array}{l}.055 \\
(.176)\end{array}$ \\
\hline$>4$ & $\begin{array}{l}-.275^{* *} \\
(.079)\end{array}$ & $\begin{array}{l}-.233^{* *} \\
(.078)\end{array}$ & $\begin{array}{l}-.303^{* *} \\
(.133)\end{array}$ & $\begin{array}{l}-.251^{*} \\
(.120)\end{array}$ \\
\hline Sample Size & 672 & 217 & 271 & 82 \\
\hline
\end{tabular}

The full specification is estimated. Coefficients for the other variables are not reported. Note: Financial assets do not include DC plan assets.

$* *=$ underlying Probit coefficient is statistically significant at 5\% level

$*$ = underlying Probit coefficient is statistically significant at $10 \%$ level 